J. Clin. Chem. Clin. Biochem.

Vol. 15,1977 , pp. $431-432$

\title{
Head-Space Analysis for the Quantitative Determination of Trichloroethylene and Tetrachloroethylene in Oils and Liquid Paraffin
}

\author{
By H.J. Drexler and Gudrun Osterkamp \\ Bundesanstalt für Fettforschung, Münster, Germany
}

(Received January 5/May 2, 1977)

\begin{abstract}
Summary: In the present study a head-space analysis is described for the determination of trichloroethylene and tetrachloroethylene in oils and liquid paraffin. The substances were separated on a column packed with $15 \%$ Apiezon $\mathrm{M}$ on Celite 545, using a temperature program. For quantitative analysis of the solvents, methyl caproate was used as an internal standard.
\end{abstract}

\section{Quantitative head-space Analyse von Trichlorethylen und Tetrachlorethylen in Ölen und Paraffinen}

Zusammenfassung: Es wird eine „head-space“-Analyse zur quantitativen Bestimmung von Trichlorethylen und Tetrachlorethylen in Ölen und Paraffinen beschrieben. Die Verbindungen werden gaschromatographisch auf einer Säule mit 15\% Apiezon M auf Celite 545 als Trägermaterial getrennt. Als innerer Standard diente für die quantitative Bestimmung Capronsäuremethylester.

\section{Introduction}

The present study results from the need to detect trichloroethylene and tetrachloroethylene in an oil-paraffin mixture, which was used for the hemodialysis of a woman who had poisoned herself with a mixture of trichloroethylene and tetrachloroethylene.

These solvents are used for the extraction of fats and oils, for caffeine extraction from coffee, for oleoresine extraction from spices, for vapor degreasing and for dry cleaning. Because these solvents have highly toxic effects $(1,2)$, it is necessary to remove all traces from food products and minimize their atmospheric concentration in factories.

Several methods are known for the detection of traces of solvents in oil or paraffin. A gravimetric method (3) and a rapid colorimetric method for the determination of residual solvents (4) are not sensitive enough. The same is true for the method developed by Eisdorfer \& Mehlenbacher (5) for the determination of trichloroethylene in plant oils after extraction with xylene. Rather sensitive detection is possible by gas chromatography. Thus, Watts \& Holswade (6) injected the oil directly on the GC column. Theiler (7) adapted this method for the detection of residual solvent in oils. For example, oleoresine is injected onto a precolumn packed with silica gel. The carrier gas, nitrogen, takes the solvents out of the sample into the separation column. By this means only readily volatile substances are detected. Herbolsheimer \& Funk (8) developed a head-space method for the detection of trichloroethylene and its metabolites in blood and urine of humans, who had been exposed to this solvent.

Because vegetable oil and low-viscosity liquid paraffin shows the same interfering peaks in the gas-chromatogram, liquid paraffin (Merck Nr. 7174) was used for the following operations.

\section{Material and Methods}

A Perkin-Elmer gas chromatograph Modell F 30, equipped with a flame ionization detector was used. Injector temperature was maintained at $150^{\circ} \mathrm{C}$, detector temperature at $200^{\circ} \mathrm{C}$. Flow rates were $20 \mathrm{ml} / \mathrm{min}$ nitrogen (carrier gas), $30 \mathrm{ml} / \mathrm{min}$ hydrogen, and $70 \mathrm{ml} / \mathrm{min}$ oxygen. A stainless steel column $(1.8 \mathrm{~m} \times 3 \mathrm{~mm}$ I. D.) was packed with $15 \%$ Apiezon $M$ on Celite 545, 60-100 mesh. The column was temperature programmed: Initially, 7 min at $90^{\circ} \mathrm{C}$; then programming, $90^{\circ} \mathrm{C}$ to $98^{\circ} \mathrm{C}$ at the rate of $1{ }^{\circ} \mathrm{C} / \mathrm{min}$; finally, 6 min at $98^{\circ} \mathrm{C}$. Peak areas were determined using the Perkin-Elmer GC Data System PEP 1.

Internal standards and stock solutions

It is known that by head-space analysis only a part of the total solute is detected. For the quantitative determination of volatile solvents, it is therefore necessary to establish the relation be- 
tween the areas and quantities of internal standards and stock solutions having different contents of trichloroethylene and tetrachloroethylenc. The internal standard was added as a solution of $44 \mathrm{mg} / \mathrm{l}$ methyl caproate in low-viscosity liquid paraffin. Ten stock solutions with different concentrations of trichloroethylene and tetrachloroethylene were prepared by weighing these compounds into liquid paraffin. The solutions were mixed by shaking vigorously for 20 minutes.

\section{Head-space analysis}

Stock solution, $500 \mathrm{mg}$, and $500 \mathrm{mg}$ internal standard solution were weighed into a $10-\mathrm{ml}$ septum bottle provided with butyl rubber septum and aluminium seal. After heating the sample for 20 minutes at $135^{\circ} \mathrm{C}, 4 \mathrm{ml}$ of the head-space gas was injected into the gas chromatograph with a syringe, which was at room temperature.

\section{Results}

\section{Retention time, recovery}

The relative retention times were: methyl caproate, $\mathrm{RRT}=1.00$; trichloroethylene, $\mathrm{RRT}=0.31$ and tetrachloroethylene, $R R T=0.65$. All analyses were performed in triplicate. The results of the recovery experiments are reported in table 1.

\section{Degree of reproducibility}

Seven paraffin samples containing $22.01 \mathrm{mg} / 1$ trichloroethylene and $22.1 \mathrm{mg} / \mathrm{l}$ tetrachloroethylene were analyzed to investigate the reproducibility of the method. The standard deviation for trichloroethylene was $s=0.68$ and for tetrachloroethylene $s=0.93 \mathrm{mg} / \mathrm{l}$.

\section{Discussion}

A simple and rapid method is described for the determination of traces of trichloroethylene and tetrachloroethylene in oil or paraffin. By means of gas chromatography, traces of solvents are detected in the head-space of the sample. It was found that Apiezon $\mathrm{M}$ is an efficient stationary phase, not only for the detection of nonsubstituted hydrocarbons, but also for the analysis of mixtures of chlorinated solvents.

Under the gas chromatographic conditions used, the head-space over paraffin and oil shows several interfering peaks during the first fifteen minutes. Therefore, it was necessary to employ an internal standard with a retention time greater than fifteen minutes. Since no chlorinated solvents met these requirements, methyl caproate was used for the quantitative detection of solvents.

Under the conditions specified above, in a $500 \mathrm{mg}$ sample, the lowest amounts that can be detected with adequate reproducibility are $0.2 \mu \mathrm{g}$ each of trichloroethylene and tetrachloroethylene.

The concentration of trichloroethylene and tetrachloroethylene in the paraffin - oil mixture, which was needed for hemodialysis, was analysed for three days according to the method described above. The mixture must be replaced two times a day, because these solvents concentrated only to the maximum of $8.8 \mathrm{mg} / 1$.

Table I: Determination of trichloroethylene and tetrachloroethylene in ten stock solutions

\begin{tabular}{|c|c|c|c|c|c|c|}
\hline \multirow[b]{2}{*}{$\begin{array}{l}\text { Stock } \\
\text { solutions }\end{array}$} & \multicolumn{3}{|c|}{ Trichloroethylene } & \multicolumn{3}{|c|}{ Tetrachloroethylene } \\
\hline & Added (mg/l) & Recovered (mg/l) & Recovery (\%) & Added (mg/l) & Recovered (mg/l) & Recovery (\%) \\
\hline I & 7.04 & 6.86 & 97.4 & 38.19 & 38.19 & 100 \\
\hline II & 8.71 & 8.14 & 93.4 & 35.46 & 35.45 & 99.9 \\
\hline III & 11.26 & 11.35 & 100.7 & 32.91 & 32.56 & 98.9 \\
\hline IV & 12.4 & 12.4 & 100 & 32.41 & 31.46 & 100.1 \\
\hline V & 14.08 & 13.9 & 98.7 & 28.95 & 28.07 & 96.9. \\
\hline VI & 21.88 & 21.82 & 99.7 & 22.15 & 22.14 & 99.9 \\
\hline VII & 26.4 & 23.14 & 87.6 & 17.34 & 17.16 & 98.9 \\
\hline VIII & 28.67 & 28.6 & 99.7 & 14.34 & 14.34 & 100 \\
\hline IX & 30.27 & 28.95 & 95.6 & 9.9 & 11.7 & 118.1 \\
\hline $\mathbf{X}$ & 39.78 & 38.19 & 96 & 4.84 & 5.45 & 112.6 \\
\hline
\end{tabular}

References

1. Seltzer, 'R. J. (1975), Chem. Eng. News, 53, Nr. 20, 41-43.

2. Kimmerle, G. \& Eben, A. (1973), Arch. Toxicol., 30, 127-138.

3. DGF-Einheitsmethoden (1968), B-II, 8, Wissenschaftliche Verlagsgesellschaft, Stuttgart, 1950-1975.

4. Pardun, H. \& Vogel, P. (1972), Fette, Seifen, Anstrichmittel, $74,69-72$
5. Eisdorfer, I. \& Mehlenbacher, V. C. (1951), J. Am. Oil Chem. Soc., 28, 307-310.

6. Watts, J. O. \& Holswade, W. (1967), J. Ass. Off. Anal. Chem., $50,717-726$.

7. Theiler, K. (1972), Dissertation, Universität Münster.

8. Herbolsheimer, R. \& Funk, L. (1974), Arch. Toxicol., 32, 209-215. 